derived by interaction between charnockite magmas and pyroxene granulites of the basement. The "Basic" division of Holland consists principally of pyroxene granulites and interstratified quartzo-felspathic garnetiferous sillimanite gneisses (khondalite), while his "Ultrabasic" division is represented by pyroxenitic schlieren, neither the "Basic" nor "Ultrabasic" divisions being related to the charnockite suite. The charnockite suite of rocks is considered to be of primary igneous origin, and to have been emplaced as thick sheets and lenses in gently folded basement rocks; all the rock units have later suffered intense regional deformation.

\section{Automatic Centrifuge}

AN eight-page folder issued recently by Ivan Sorvall, Inc., Norwalk, Connecticut, illustrates and describes the super-speed Servall $S S-3$ Automatic Centrifuge and the SS-4 Enclosed Centrifuge. Both instruments are table-top models with a marked versatility in accepting any one of five different rotors covering a wide range of batch capacities, speeds and gravitational forces. After the desired operating speed, running time, and rate of deceleration have been pre-set on the SS-3's conveniently angled control panel, the circuit is actuated by the push of a button. A particular advantage of the automatic controls is the accuracy with which a given operation may be repeated and complete uniformity of result maintained. The $S S-4$ is a manually controlled instrument and the complete control panel is removable for remote operation. This is convenient when work demands operation in cold rooms or fume hoods. Both centrifuges are designed for rapid adaptation to continuous flow operation with the Servall 'Szent-Györgyi and Blum' system, which allows the collection of small amounts of precipitate, in tubes, from gallon quantities of samples.

\section{University News : Queen's University of Belfast}

THE following appointments to lectureships are announced : Dr. C. J. M. Stirling, organic chemistry ; Dr. J.S. Pate, botany ; Dr. B. V. Jayawant, electrical engineering ; N. C. Mitchel, geography; W. D. Ryan, light electrical-engineering.

Bristol

THE appointment has been announced of Dr. W. M. Shepherd, reader in the University, to the chair of theoretical mechanics. The following have been appointed to lectureships: P. W. Bothwell, public health; D. R. Coles, medicine; D. G. Osmond, anatomy; R. Park, civil engineering; N. G. Sanerkin, pathology.

\section{London}

THE following appointments have been made: Prof. J. L. D'Silva, professor of physiology at London Hospital Medical College, to the Halliburton chair of physiology tenable at King's College; A. H. J. Rains, senior lecturer in the University of Birmingham, to the chair of surgery tenable at Charing Cross Hospital Medical School. The following have been appointed readers: Dr. G. R. Hilson, bacteriology, and Dr. D. Dexter, morbid anatomy, tenable at St. George's Hospital Medical School; J. F. Smith, morbid anatomy, tenable at University College Hospital Medical School ; R. E. M. Thompson, bacteriology, tenable at the Middlesex Hospital
Medical School; Dr. P. J. Grant, engineering science, and Dr. B. W. Martin, applied thermodynamics, tenable at the Imperial College of Science and Technology ; E. M. Rawstron, geography, tenable at Queen Mary College. The title of reader in the University of London has been conferred on : T. E. Hughes, zoology, in respect of his post at Birkbeck College; Dr. J. Wynn Reeves, psychology, in respect of her post at Bedford College; Dr. J. H. Trounce, therapeutics, in respect of his post at Guy's Hospital Medical School.

\section{University College of North Staffordshire}

The U.S. Rubber Co. has founded a second postgraduate research studentship at the College. J. Penfold (Nottingham) and J. Beard (Southampton) have been appointed to these studentships. The Phillips Petroleum Co. of Bartlesville, Oklahoma, has founded a postgraduate research studentship at the College, to which C. J. Panton (Southampton) has been appointed. All three research students will work with Dr. P. H. Plesch on problems related to cationic polymerization.

\section{Announcements}

The Institute of Physics is to hold a conference on Some Aspects of Magnetism during September 22-24 at Sheffield. Further information may be obtained from the Secretary, Institute of Physics, 47 Belgrave Square, London, S.W.1.

AN informal Discussion on Flow Properties of Blood and Other Biological Systems, sponsored jointly by the British Society of Rheology and the Colloid and Biophysics sub-Committee of the Faraday Society, will be held in the Department of Physiology, Oxford, during September 23-24. Further information may be obtained from Dr. A. L. Copley, Medical Research Laboratories, Charing Cross Hospital, Strand, London, W.C.2, or from Dr. G. Stainsby, British Gelatine and Glue Research Association, 2a Dalmeny Avenue, London, N.7.

A symposium on Depression will be held at the University of Cambridge Post-Graduate Medical School during September 22-26. Information may be obtained from the Secretary, Medical School, Tennis Court Road, Cambridge.

The 250th anniversary of the successful use of coke in ironmaking is to be celebrated by a meeting at the University of Birmingham and at Coalbrookdale, Shropshire, during September 23-25. Further information can be obtained from the Secretary, Iron and Steel Institute, 4 Grosvenor Gardens, London, S.W.1.

THE Institute of the Rubber Industry is to hold a conference on Industrial Technical Organization at the Palace Hotel, Southport, during October 9-10. Information can be obtained from the Conference Secretary, Institution of the Rubber Industry, 4 Kensington Palace Gardens, London, W.8.

The Committee on Geodesy and Geophysics of the Academy of Sciences of the U.S.S.R. published in 1957 a short report of 75 pages on the recent work done in the Soviet Union in the field of seismology, seismo-geology, seismological survey, physics of the earth, tectonophysics and the age determination of minerals and rocks. A list of seismological stations, abstracts of some of the papers and bibliographies of others are given. 